\title{
PERANCANGAN ANIMASI EDUKASI BAHASA INGGRIS TINGKAT DASAR
}

\author{
Ispandi ${ }^{1)}$, M Hilman Fakhriza ${ }^{2)}$ \\ 1 Teknik Informatika, STMIK Nusa Mandiri \\ email: ispandi.ipd@nusamandiri.ac.id \\ 2 Teknik Informatika, STMIK Nusa Mandiri \\ email: m.hhz@nusamandiri.ac.id
}

\begin{abstract}
Abstrak
Dengan semakin berkembangnya teknologi, peranan aplikasi edukasi dalam dunia pendidikan semakin penting. Hampir diberbagai tingkat pendidikan, mulai dari usia balita sampai tingkat yang lebih tinggi digunakan sebagai media alternatif dalam bidang pendidikan maupun ilmu penggetahuan. Berbagai tema yang di ambil semakin beragam, diantaranya belajar bahasa asing, pendidikan TK (Taman Kanak-Kanak), pendidikan SD (Sekolah Dasar). Tujuan penelitian ini untuk mengetahui (1) Aplikasi edukasi memberikan banyak kemudahan bagi para pendidik dalam memberikan ilmu pengetahuan maupun pembelajaran bagi anak-anak mereka diluar dari pendidikan sekolah, bukubuku, ataupun media lainnya. (2) sebagai sarana bagi anak-anak yang telah berusia 6-9 tahun untuk dapat mengenal bahasa inggris bermacam-macam kosakata yang ada disekitar mereka dengan hal yang lebih mengasikan dan lebih mudah di pahami dan di ingat bagi anak di usia 6-9 tahun. (3) mengetahui respon anak dalam menerima pembelajaran dengan animasi. Dalam penulisan ini penulis menggunakan aplikasi flash untuk membuat animasi edukasi Bahasa inggris tingkat dasar. Metode penelitian yang di gunakan adalah metode pengembangan Model ADDIE yang memiliki lima tahapan yaitu analisis, design, pengembangan, implementasi dan evaluasi. Tahapan implementasi di lakukan pengujian kepada anak anak usia 6-9 tahun untuk mengetahui kevalidan media pembelajaran dan isi materi apakah sudah sesuai sehingga media pembelajaran dapat di terapkan. Sedangkan untuk evaluasi di lakukan uji coba terhadap kelompok siswa siswi sekolah dasar. Hasil uji coba rata rata respon siswa siswi sekolah dasar terhadap animasi edukasi pembelajaran Bahasa Inggris yaitu $77 \%$ menjawab bahwa animasi edukasi Bahasa Inggris tingkat dasar ini membantu mereka dalam memahami Bahasa Inggris. Dengan begitu media pembelajaran animasi Bahasa Inggris tingkat dasar dapat membatu siswa siswi dalam mengingat Bahasa Inggris.
\end{abstract}

Kata kunci: Aplikasi Edukasi, Mengenal Bahasa Inggris, Belajar Bahasa Inggris

\begin{abstract}
With the development of technology, the role of educational applications in education increasingly important. Almost at various levels of education, ranging from toddlers to higher levels are used as an alternative media in the field of education and science penggahuan. Various themes are taken more diverse, including learning a foreign language, kindergarten education (Kindergarten), elementary education (Primary School). The purpose of this study is to find out (1) Educational applications provide many facilities for educators in providing science and learning for their children outside of school education, books, or other media. (2) as a means for children who are aged 6-9 years old to be able to recognize english various vocabulary that is around them with things that more mengasikan and more easily understood and remembered for children at age 6-9 years . (3) to know the response of children in receiving learning with animation. In this paper the authors use flash applications to create a basic educational English language animation. The research method used is the development method of ADDIE Model which has five stages: analysis, design, development, implementation and evaluation. Implementation phase in testing to children aged 6-9 years to know the validity of the learning media and the content of the material is appropriate so that the learning media can be applied. While for the evaluation conducted a trial of a group of elementary school students. The result of the average of the response of the students of elementary school students to the animation of English learning education is $77 \%$ replied that the animation of basic level English education helps them understand English. With so basic learning media animation English language can help students in remembering English.
\end{abstract}

Keywords: Educational Applications, Know English, Learn English 


\section{PENDAHULUAN}

Perkembangan dunia komputer saat ini semakin berkembang pesat dalam berbagai bidang. Bidang tersebut baik dalam ekonomi, sosial, budaya maupun pendidikan. Dengan berkembangnya ilmu pengetahuan dan teknologi, setiap bidang usaha membutuhkan informasi dengan cepat dan akurat, dengan teknologi dapat mempermudah pekerjaan manusia.

Kebutuhan akan teknologi kini tidak terbatas untuk semua kalangan, dari kalangan remaja hingga kalangan dibawah umur kini telah diperkenalkan teknologi sejak dini. Dengan semakin meningkatkan perkembangan teknologi dalam bidang pendidikan. Contoh kecilnya adalah semakin berkembangnya teknologi aplikasi pendidikan yang bisa disetarakan dengan karya-karya negara maju lainnya.

Perkembangan teknologi memungkinkan sistem pendidikan dengan menciptakan dan menggabungkan sejumlah pembelajaran yang berbeda bahan. Namun, masih ada kesenjangan besar antara teknologi maju dan pemahaman kita tentang bagaimana manusia bisa menjadi belajar dengan baik dengan bantuab teknologi. Teori Pembelajaran Multimedia. Berdasarkan asumsi bahwa peserta didik bekerja Memori terbatas dalam kapasitas dan terstruktur dalam pendengaran dan saluran visual, pelajar harus memilih dan mengatur informasi verbal dan visual baru untuk membangun model tunggal, dan mengintegrasikannya. Pengetahuan yang ada untuk membangun model pembelajaran yang lebih baik(Gouaty et al., 2016).

Anak akan semakin berkembang jika diperkenalkan teknologi dalam masa perkembangannya. Dalam hal ini anak pada usia SD 6-9 tahun adalah saat mengenal dan mempelajari hal-hal baru yang ada di sekelilingnya. Dengan terbiasanya menggunakan aplikasi sejak dini, maka tidak menutup kemungkinandewasa nanti mereka akan lebih terbiasa menggunakan aplikasi yang lebih rumit. Dengan begitu mereka akan bisa mengikuti perkembangan teknologi yang ada.

\section{IDENTIFIKASI MASALAH}

Bagaimana memberikan metode pembelajaran baru bagi anak-anak dalam pengenalan Bahasa Inggris tingkat dasar dengan menggunakan teknologi. Dan juga dapat membantu orang tua ataupun guru dalam mengajarkan anak-anaknya tentang Bahasa Inggris tingkat dasar dan membantu menumbuhkan rasa senang dalam belajar pada anak dan memaksimalkan proses penerimaan suatu informasi dengan lebih baik pada usia dini.

\section{TINJAUAN PUSTAKA}

\section{Animasi}

Animasi dinyatakan sebagai gambar karena penyajian beberapa gambar, dinyatakan sebagai gambar gerak karena menyajikan gambar-gambar yang bergerak dan dinyatakan sebagai simulasi karena animasi terdiri dari objek atau gambar yang dapat menggambarkan simulasi (Andi, 2011:2).

Animasi adalah suatu gerakan objek gambar atau teks yang diatur sedemikian rupa sehingga kelihatan bergerak. Kesan bergerak ini didapat akibat adanya peralihan dari satu gambar ke gambar lainnya dalam satuan waktu yang disebut dengan frame. Dalam arti lain animasi adalah persepsi yang terjadi akibat perpindahan frame dalam satu waktu. Membuat animasi berarti menyusun sebuah objek, gambar atau lukisan yang diam menjadi seakan-akan hidup atau bergerak. Teknik pembuatan animasi telah berubah seiring dengan perkembangan teknologi komputer(García, Quirós, Santos, González, \& Fernanz, 2007).

Efisiensi pengerjaan pembuatan animasi telah dilakukan sejak diperkenalkan teknik animasi, cell (celluoid Sheet, semacam kertas transparansi). Gagasan dari sel adalah satu gambar dibuat dalam satu frame. Perubahan kecil dibuat dalam frame berikutnya sampai 
perubahan yang berarti yaitu keyframe. Animasi yang di bentuk oleh frame-frame antara 2 keyframe disebut in-between, biasanya dibuat oleh animator sendiri. Biasanya animasi selalu dibuat dengan tambahan dari beberapa komponen lainnya seperti teks, suara, cahaya dan lainnya. Untuk tipe file suara hannya ada beberapa saja yang dapat dipakai dalam program macromedia pro 8 diantaranya, yaitu :

a. Animasi Frame per Frame

Animas frame per frame adalah animasi yang diatur di setiap frame, mulai dari perubaha gerak, bentuk, posisi atau warna objek. Semakin banyak frame yang disunakan untuk manampung setiap detil gerakan objek, semakin halus animasi yang di hasilkan.(Andi, 2011:134)

b. Animasi Gerak

Selain menggunaka animasi frame By Frame, Macromedia Flash Pro 8 menyedia fasilitas animasi yang dibentuk dengan pergerakan farme-frame dari titik ke titik pada suatu objek gambar yang ada.( Andi, 2011:137)

Dibawah ini macam-macam animasi bergerak, di antaranya adalah :
a. Animasi objek bergerak tanpa jejak
b. Animasi objek bergerak dengan jejak
c. Animasi objek perubahan bentuk

\section{Pembelajaran pada anak}

Penelitian yang dilakukan oleh Laura Hasiel dengan judul "Multimedia dalam pembelajaran" pada tahun 2010 menuliskan bahwa sesuai dengan kurikulum tingkat satuan pendidikan (KTSP) yang berlaku sekarang, menyebutkan salah satu prinsipnya yaitu tanggap terhadap ilmu pengetahuan, teknologi dan seni berkembang secara dinamis. Oleh karena itu, semangat dan isi kurikulum serta pembelajarannya harus memberikan pengalaman belajar serta didik untuk mengikuti dan memanfaatkan perkembangan ilmu pengetahuan, teknologi dan seni. Bagaimana pengaruh dan keefektivitasan multimedia pada embelajaran di sekolah dasar?

Multimedia adalah menggunakan komputer untuk menyajikan dan menggabungkan teks, suara, gambar, animasi dan video dengan alat bantu (tool) dan koneksi (link) sehingga pengguna dapat ber-(navigasi), berkarya dan berkomunikasi (García et al., 2007). Apabila dikaitkan antara multimedia dan pembelajaran maka pembelajaran itu dapat menarik, efektif dan efisien apabila menggunakan multimedia sebagai media pembelajarannya. Dipilih multimedia karena kita harus ingat bahwa masa kanak-kanak terutama siswa sekolah dasar karena mereka masih berfikir konkrit, semua yang guru utarakan atau sampaikan harus mereka buktikan sendiri dengan mata mereka, kemudia multimedia merupakan sumber belajar yang berisikan pesan atau materi pembelajaran yang dibuat secara menarik dalam bentuk kombinasi gambar, teks, gerak animasi yang disesuaikan dengan usia peserta didik yang dapat menarik minat peserta didik dalam belajar, sehingga pembelajaran akan menyenangkan dan tidak menjenuhkan.(Novitasari, 2010).

\section{Perangkat Lunak}

Macromedia Flash Professional 8, Adobe Photoshop 7.0, Free Audio Editor.

\section{Metode Penelitian}

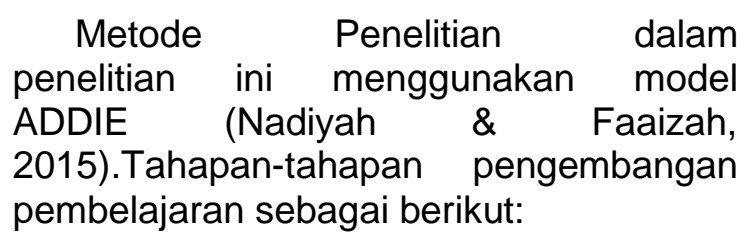

a. Analysis (Analisis) yaitu melakukan analisis kebutuhan, mengidentifikasi masalah (kebutuhan) di anak usia 6-9 tahun dalam memahami pelajaran Bahasa Inggris.

b. Design (Desain) media dilakukan dengan menyusun buram media. Pengembangan media diawali dengan menyusun buram media. 
Media yang dihasilkan dinyatakan sebagai buram sampai dengan selesainya proses validasi dan uji coba.

Tahap desain merupakan langkah awal dalam pembuatan animasi dan harus mempersiapkan segala sesuatu yang akan dibutuhkan antara lain penulisan cerita dan

c. Development Merupakan proses mewujudkan rancangan tersebut menjadi kenyataan Adapun bentuk dari media yang digunakan adalah dalam bentuk film animasi 3 dimensi. Hasil dari tahap ini adalah sebuah produk yaitu berupa media pembelajaran animasi 3D yang sudah terstruktur sesuai dengan standar kompetensi, kompetensi dasar dan indikator dimana ketiganya sudah termuat dalam setiap uraian materi. Pada tahap pengembangan ini animasi

dibuat sesuai kebutuhan dari tahap pengembangan yang telah dirancang, seperti: Modelling, Texturing, Ringging, Skining, Acting/Animation, Lighting, Rendering, Tahap Perekaman, dan Tahap Penggabungan.

d. Implementation (Implementasi) merupakan tahap uji coba atau menerapkan media pembelajaran kepada siswa siswi yang masih duduk di bangku sekolah dasar mengetahui kesesuaian/validitas media terhadap materi pelajaran.

e. Evaluation (Evaluasi) merupakan tahap untuk melihat keberhasilan dari media pembelajaran yang dikembangkan apakah sesuai dengan harapan semula. Evaluasi bertujuan untuk melakukan penyempurnaan terhadap media pembelajaran yang telah dikembangkan.

\section{Pengenalan Macromedia Flash Professional 8}

Macromedia Flash Professional 8 merupakan program animasi standar professional yang mudah digunakan dan sangat berguna untuk membuat animasi, dari animasi sederhana sampai animasi kompleks, meliputi multimedia dan aplikasi web yang dinamis dan interaktif. Macromedia Flash Professional 8 merupakan versi terbaru dari seri Macromedia Flash mx 2004 yang ada.

Sekarang ini sudah banyak aplikasi yang dihasilkan dengan menggunakan flash seperti : desain web, presentasi interaktif, pembuatan sebuah game, dan hingga digunakan untuk pembuatan film animasi pendek. Dalam perkembangannya, banyak aplikasi grafis dan aplikasi animasi yang melengkapi fasilitasnya untuk dapat diintegrasikan dengan program Macromedia Flash. (Carvalho, Marroquim, \& Vital Brazil, 2017)

Macromedia Flash versi terbarunya Macromedia Flash Professional 8 yang dikemas dalam satu paket dengan nama Macromedia All in One. Pada versi terbarunya ini telah dilengkapi berbagai fasilitas yang mampu meningkatkan kinerja program dalam pembuatan obyek flash yang dapat diintegrasikan secara langsung pada halaman web termasuk didalamnya adalah animasi flash.

\section{1) Toolbox}

Toolbox merupakan perangkat utama menggambar dalam flash, toolbox terbagi dalam empat bagian, yaitu : tool, view, color, dan option.

Tools selain terdiri atas hand yang digunakan untuk memindahkan stage dan perangkat zoom zoom yang digunakan untuk memperbesar dan memperkecil gambar. View menyediakan perangkat hand yang digunakan untuk memindakan stage dan perangkat zoom yang digunakan untuk memperbesar dan memperkecil gambar. Colors menyediakan perangkat untuk mewarnai dan mengubah bentuk garis, mewarnai isi objek dan teks, bagian akhir toolbox, yaitu option memperlihatkan settingsetting optional untuk tool yang sedang aktif. Jika toolbox tidak terlihat dilayar, kita bisa menampilakannya dengan menggunakan menu windows > tools. 


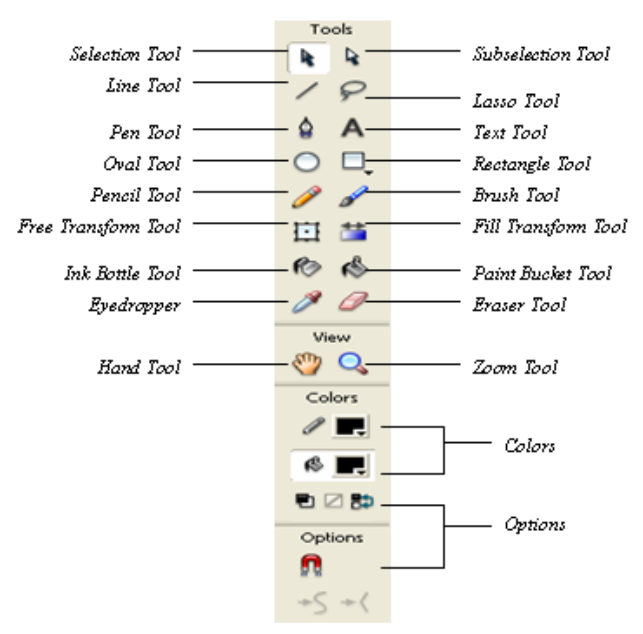

Gambar 1. Toolbox

Tabel 1. Keterangan Fungsi Toolbox

\begin{tabular}{|c|c|}
\hline Gambar & Keterangan \\
\hline 4 & $\begin{array}{l}\text { Arrow tools digunakan untuk } \\
\text { memilih dan memindahkan } \\
\text { objek }\end{array}$ \\
\hline 8 & $\begin{array}{lll}\text { Subselect } & \text { tools } & \text { untuk } \\
\text { memodifikasi } & \text { titik-titik } & \text { suatu } \\
\text { garis pada gambar } & \end{array}$ \\
\hline l & $\begin{array}{l}\text { Line tool untuk membuat } \\
\text { garis lurus }\end{array}$ \\
\hline 0 & $\begin{array}{l}\text { Lasso tool untuk memilih } \\
\text { bagian dari objek } \\
\text { memilih objek yang tidak } \\
\text { teratur }\end{array}$ \\
\hline 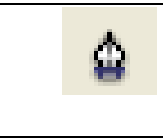 & $\begin{array}{l}\text { Pen tool untuk menambah } \\
\text { atau mengurangi titik-titik } \\
\text { pada garis suatu gambar }\end{array}$ \\
\hline $\mathrm{A}$ & Teks tool untuk menulis teks \\
\hline 0 & $\begin{array}{l}\text { Oval tool untuk membuat } \\
\text { gambar lingkaran atau oval }\end{array}$ \\
\hline$\square$. & $\begin{array}{l}\text { Ractangle tool untuk } \\
\text { membuat persegi atau kotak }\end{array}$ \\
\hline 8 & $\begin{array}{ll}\text { Pencil tool } & \text { untuk } \\
\text { menggambar bentuk yang } \\
\text { teratur }\end{array}$ \\
\hline 8 & $\begin{array}{l}\text { Brush tool untuk } \\
\text { menggambar bebas dengan } \\
\text { sistem seperti kuas }\end{array}$ \\
\hline 6 & $\begin{array}{l}\text { Ink Bottle tool untuk } \\
\text { mewarnai atau menambah } \\
\text { warna outline suatu objek }\end{array}$ \\
\hline$\$$ & $\begin{array}{l}\text { Paint Bucket tool untuk } \\
\text { mengidentifikasi warna fiil }\end{array}$ \\
\hline
\end{tabular}

\begin{tabular}{|c|l|}
\hline & suatu objek \\
\hline \multirow{2}{*}{$\begin{array}{l}\text { Dropper tool untuk } \\
\text { mengambil warna suatu } \\
\text { bidang }\end{array}$} \\
\hline \multirow{3}{*}{$\begin{array}{l}\text { Eraser tool untuk menghapus } \\
\text { sebagian atau seluruh objek } \\
\text { yang tidak diinginkan }\end{array}$} \\
\hline $\begin{array}{l}\text { Free Transfrom tool untuk } \\
\text { mentransformasi bentuk } \\
\text { suatu objek }\end{array}$ \\
\hline $\begin{array}{l}\text { Fill Transfom tool untuk } \\
\text { mentrasformasi fill suatu } \\
\text { objek }\end{array}$ \\
\hline
\end{tabular}

2) Timeline

Timeline merupakan tool utama untuk membuat animasi dan objekobjek interaktif, timeline terdiri atas tiga bagian utama, yaitu scene, layer, dan frame. Jika animasi diumpamakan seperti sebuah buku yang dibuka lembar perlembar, maka timeline adalah buku tersebut, scene adalah bab-bab dalam suatu buku, layer adalah halaman buku, dan frame adalah kecepatan tangan anda dalam membuka lembaranlembaran buku tersebut.

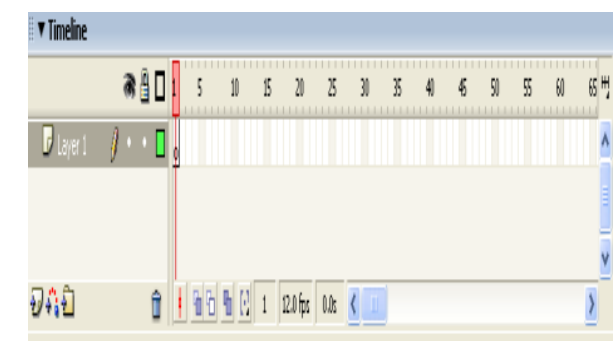

3) Stage

Gambar 2. Timeline

Stage adalah kanvas tempat meletakkan dan mengedit objekobjek flash.

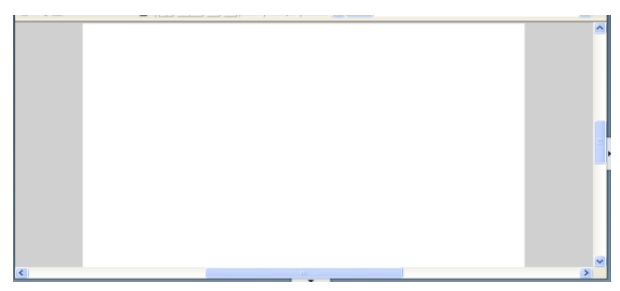

Gambar 3. Stage (Kanvas)

4) Panel Propertis 
Panel Propertis adalah panel yang menampilkan atribut dari suatu objek yang sedang aktif sehingga atribut objek tersebut dapat kita ubah.

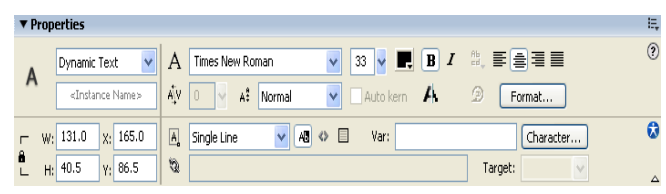

Gambar 4. Propertis

5) Panel Actions

yang Panel Action adalah panel pemograman actionsript yang digunakan untuk membuat animasi interaktf.

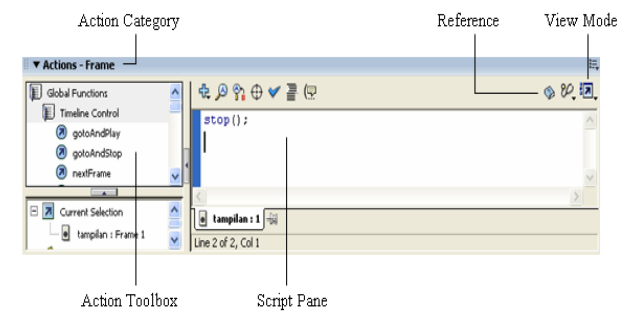

Gambar 5. Actions

Keterangan:

a. Action Category: Menunjukan action yang diberikan pada frame atau objek.

b. Reference: Digunakan untuk mengkases informasi lengkap seputar penggunaan Action Script yang ada pada help

c. Vew Mode: Digunakan untuk mengatur tampilan pada script pane

d. Action Toolbox: berisi kumpulan action yang disediakan oleh Flash, untuk menggunakannya pilih kelompok action lalu klik dua kali pada action yang digunakan.

e. Script Pane: tempat dimana kode action akan Ditulis

\section{6) Panel Colour}

Panel Colour adalah panel yang berfungsi untuk mengatur komposisi berwarna stroke maupun pada file objek.

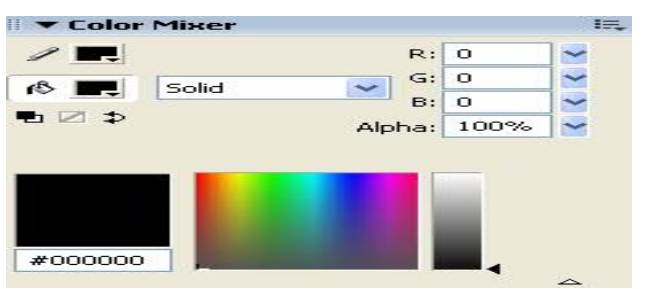

Gambar 6. Colour

\section{7) Library}

Library adalah panel yang berfungsi untuk menyimpan objekobjek yang telah dijadikan symbol.

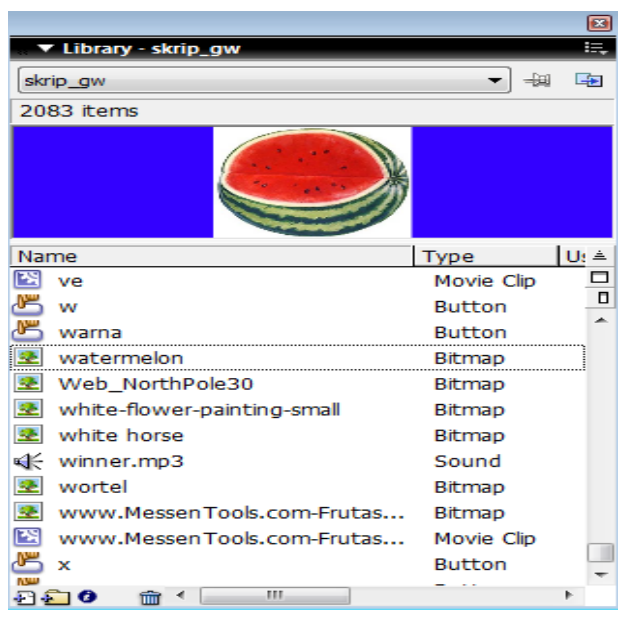

Gambar 7 Library

\section{HASIL dan PEMBAHASAN}

Perancangan Story Board

a) Story Board

Perancangan story board berisi pembahasan mengenai alur cerita dari aplikasi yang akan disampaikan dengan menggunakan tulisan dan gambar. Berikut penulis ceritakan alur dari aplikasi ini, pertama user harus men-double-click pada icon Enter.Exe. Setelah itu akan muncul opening yang nantinya akan masuk ke menu utama. Setelah itu, user bisa memilih salah satu layar dari 4 tombol. Yang pertama ada "Study", "Exercise", "Profile", "Exit". Bila siswa memilih Study, maka siswa akan dihadapkan dengan pengenalan berbagai jenis gambar dan kosakata. 
Jika Exercise maka siswa wajib memasukkan nama terlebih dahulu. Kemudian baru bisa menjawab soal sebanyak 10 pertanyaan. Lalu siswa pun dapat melihat score setelah soal ke 10 dijawab. Profile berisi profile penulis dan Exit bila ingin mengakhiri aplikasi ini.

\section{b) State Trasition Diagram}

Suatu pemodelan peralatan (modeling tool) yang menggambarkan sifat ketergantungan terhadap suatu sistem waktu nyata (real time system), dan tampilan tatap muka (interface) pada sistem aktif (online system). Pemodeln ini juga penulis gunakan dalam menjelaskan alur-alur dari aplikasi yang penulis rancang.

1. Menu Utama

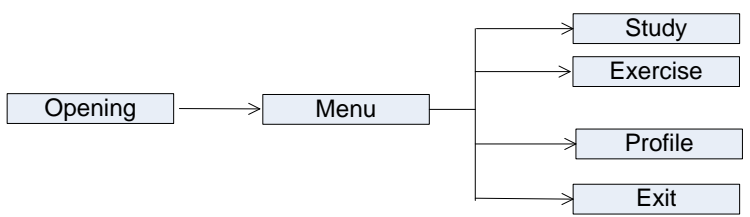

Gambar 8. State Transition Diagram Main Menu

Menggambarkan menu awal aplikasi dimana pertama kali user akan menemui opening dengan sebuah tombol enter, lalu akan masuk ke menu utama yang terdapat tombol study, exercise dan exit.

\section{Menu Study}

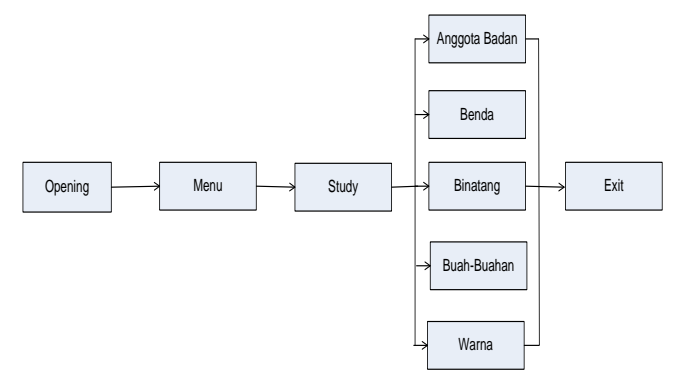

Gambar 9. State transition Diagram Menu Study

Menggambarkan menu lanjutan dari menu study. Dimana terdapat beberapa kosakata yang merupakan tombol.
3. Menu Exercise

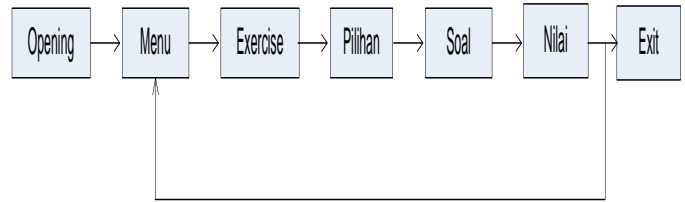

Gambar 10. State transition Diagram Menu Exercise

Menggambarkan menu lanjutan dari menu exercise. Dimana terdapat beberapa soal yang harus dijawab dan diakhir akan diperlihatkan nilai dari soal yang telah dijawab.

c) Statechart Diagram

$\begin{aligned} & \text { Statechart } \\ & \text { individu-individu } \\ & \text { objek }\end{aligned} \begin{array}{r}\text { menelusuri } \\ \text { melalui } \\ \text { heseluruhan } \\ \text { daur }\end{array}$ hidupnya,
menspesifikasikan semua urutan yang
mungkin dari pesan-pesan yang akan
diterima objek tersebut, bersama-sm
dengan tanggapan atas pesan-pesan
tersebut.

\section{State Diagram Study}
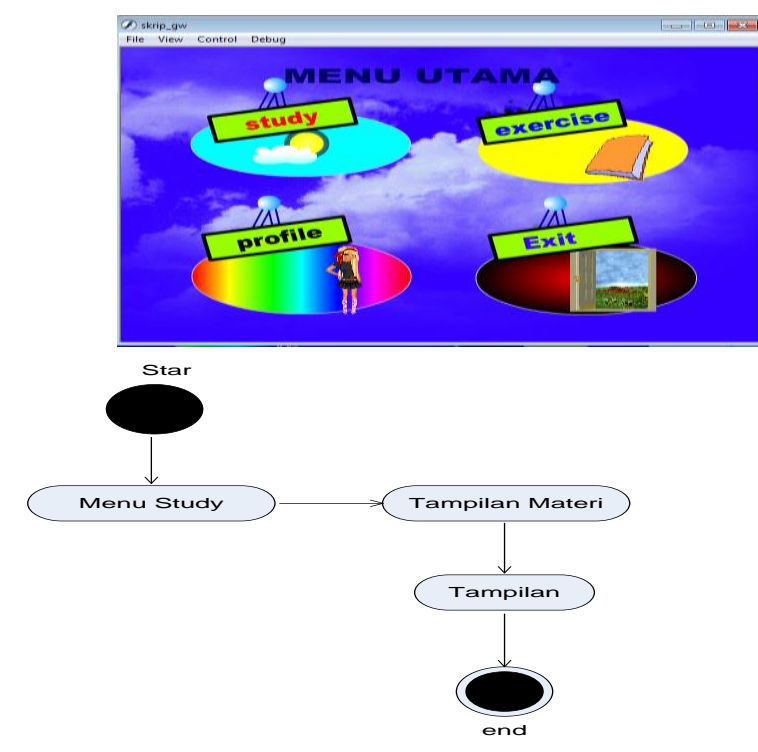

Gambar 11. State Diagram Study

Menggambarkan urutan dari sebuah menu study. User memilih menu study, maka akan keluar tampilan materi dari tombol study.

\section{State diagram Exercise}






Gambar 12. State diagram Exercise

Menggambarkan urutan dari sebuah menu exercise. User memilih menu exercise, maka akan keluar tampilan soal-soal dari materi Study. Setelah menjawab user akan dapat melihat nilai dari hasil jawaban.

\section{Perancangan User Interface}

Pada pembuatan aplikasi ini dikarenakan fungsinya yang bersifat informasi pengenalan, aplikasi ini dibuat tidak terlalu berlebihan, sehingga mampu menyesuaikan dari fungsi aplikasi ini. Pada beberapa tiap halamannya juga diberikan latar suara, sehingga mampu menambah efek menarik dari aplikasi ini. Aplikasi ini juga mudah digunakan (user friendly), tombol (button) penghubung antar satu frame dengan frame lainnya mudah diketahui, sehingga tidak mempersulit user untuk menggunakannya. Tampilan user interface dari aplikasi ini antara lain :

\section{a) Tampilan Main Menu}

Tampilan main menu ini berisi 4 button yaitu : Study, Exercise, Profile, dan tombol Exit

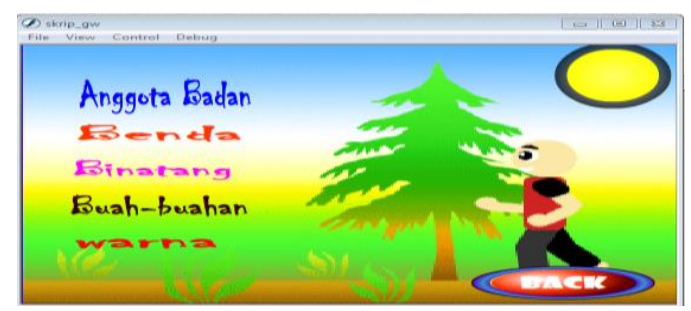

Gambar 13. Tampilan Main Menu

b) Tampilan Button Study

Tampilan ini terdapat pembelajaran tentang kosakata tentang Bahasa Inggris dan ada button back untuk kembali ke main menu.

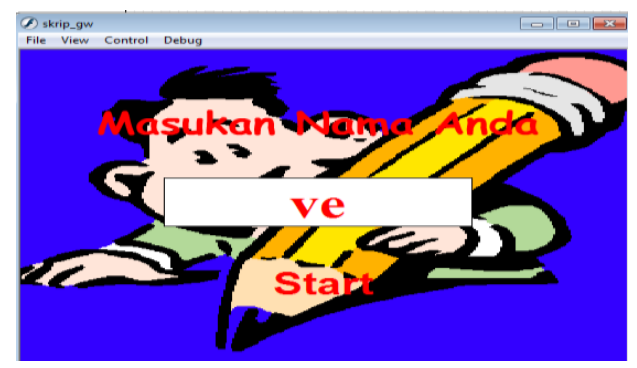

Gambar 14. Tampilan Study

c) Tampilan Button Exercise

Tampilan ini terdapat soal-soal latihan tentang Bahasa Inggris dan ada button kembali ke menu utama untuk kembali ke main menu.

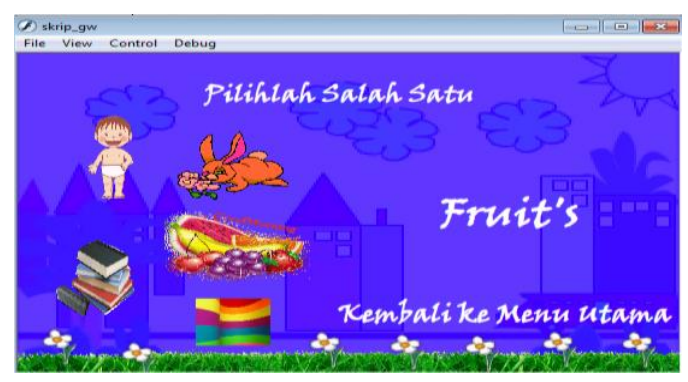

Gambar 15. Tampilan Pilihan Exercise

\section{d) Tampilan Masukan Nama}

Bila user memilih menu Exercise maka sebelumnya harus memasukkan nama pemain terlebih dahulu, setelah itu baru masuk ke pertanyaan soal. Tampilan score akan muncul sesuai dengan jawaban yang kita jawab dengan benar, terdapat tombol Menu Kembali untuk kembali ke main menu.

\section{Gambar 16. Tampilan Masukan Nama}

\section{e) Tampilan Exercise}

Tampilan exercise adalah tampilan yang keluar ketika pengguna mengklik tombol star kemudian akan muncul 10 pertanyaan yang harus dijawab. 


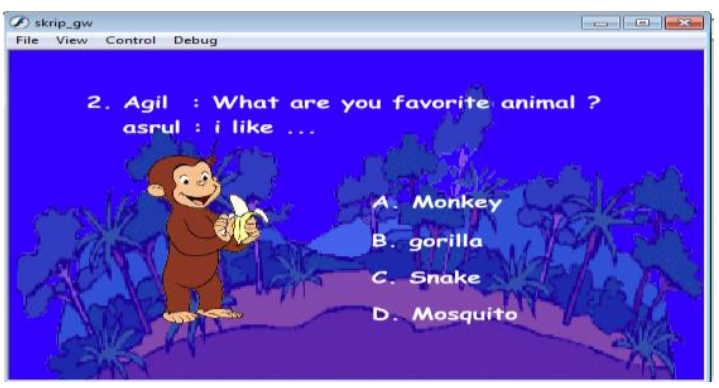

Gambar 17. Tampilan Exercise

\section{f) Tampilan Tampilan Score Nilai}

Tampilan ini adalah tampilan yang keluar ketika pengguna menyelesaikan 10 pertanyaan. Akan keluar nilai dari jumlah pertanyaan yang dijawab dengan benar.

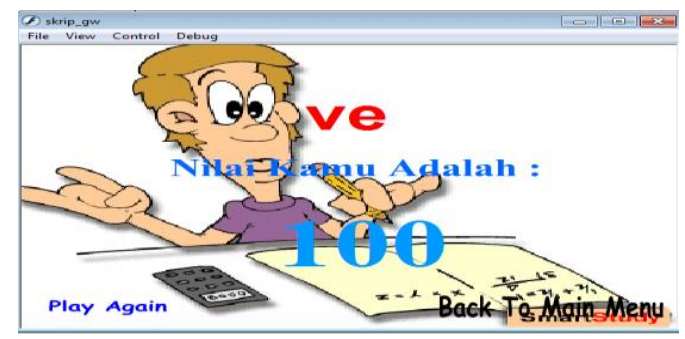

Gambar 18. ampilan Score Nilai

g) Tampilan Button Profile

Tampilan ini terdapat Profile tentang penulis dan ada button back untuk kembali ke main menu.

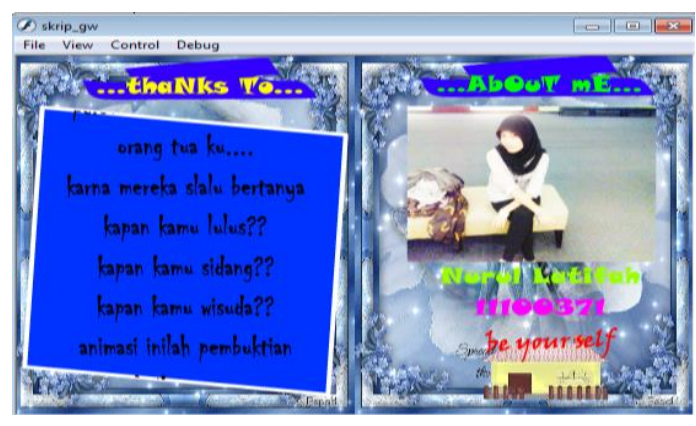

Gambar 19. Tampilan Button Profile

\section{Pengujian Sistem (Testing)}

Aplikasi animasi multimedia yang telah penulis buat, selanjutnya diuji melalui teknik pengujian perangkat unak yang meliputi pengujian black box.

\section{Pengujian White Box}

White Box Testing adalah meramalkan cara kerja perangkat lunak secara rinci, karenanya logical path (jalur logika) perangkat lunak akan di test dengan menyediakan test case yang akan mengerjakan kumpulan kondisi dan atau pengulangan secara spesifik. Secara sekilas dapat diambil kesimpulan white box testing merupakan petunjuk untuk mendapatkan program yang benar $100 \%$. Metode white box ini adalah suatu metode desain test case yang menggunakan. struktur kontrol desain prosedural untuk memperoleh test case. Dengan menggunakan metode pengujian white box(Gouaty et al., 2016), perekayasaan sistem dapat melakukan test case yang dapat :

a. Memberikan jaminan bahwa semua jalur independen pada suatu modul telah digunakan paling tidak satu kali.

b. Menggunakan semua keputusan logis pada sisi true dan false.

c. Mengeksekusi semua loop (perulangan) pada batasan mereka dan pada batas operasional mereka

d. Mengerjakan seluruh struktur data internal yang menjamin validitas

Dalam hal ini, pengujian tidak dilakukan terhadap keseluruhan program secara utuh, namun dilakukan sampel pengujian tertentu yang dijalankan. Sebagai contoh, akan dibahas pengujian terhadap soal 1, yang prinsip kerjanya sama dengan soal 2 sampai dengan soal 10 pada aplikasi ini.

\section{A. Pengujian White Box Exercise}

Secara garis besar, algoritma dari Exercise adalah sebagai berikut:

1. Masukkan nama pemain

2. Tampilan gambar atau soal 1 muncul

3. Pilih salah satu jawaban yang dianggap benar

4. Jika user biasa menjawab pertanyaan dengan nar, maka user akan mendapat score 10 ditiap gambarnya, namun jika salah akan mendapat nilai 0 tiap gambarnya. Score akan diakumulasikan di akhir permainan.

Bagan alir dari latihan soal ini adalah sebagai berikut : 


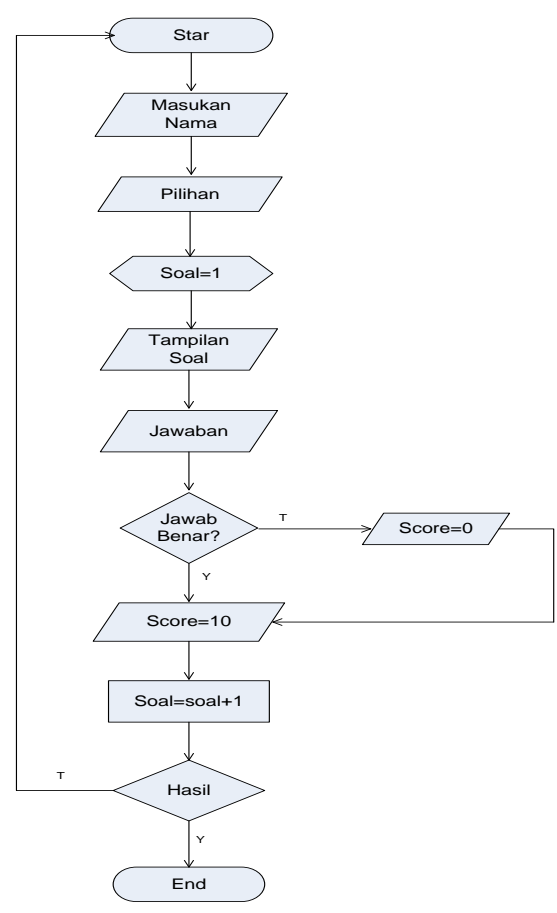

Gambar 20. Bagan Alir Exercise

2. Pengujian Black Box

Pengujian selanjutnya dilakukan untuk memastikan bahwa suatu event atau masukan akan menjalankan proses yang tepat dan menghasilkan output sesuai dengan rancangan. Untuk contoh pengujian aplikasi multimedia memberikan hasil sebagai berikut :

\begin{tabular}{|l|l|l|l|}
\hline $\begin{array}{l}\text { Input / } \\
\text { event }\end{array}$ & Proses & $\begin{array}{l}\text { Outp } \\
\text { ut/ne } \\
\text { xt }\end{array}$ & $\begin{array}{l}\text { Hasil } \\
\text { Peng } \\
\text { ujian }\end{array}$ \\
\hline $\begin{array}{l}\text { Tomb } \\
\text { ol } \\
\text { Enter }\end{array}$ & $\begin{array}{l}\text { on (release)\{ } \\
\text { gotoAndPlay } \\
\text { ("menu"); } \\
\}\end{array}$ & $\begin{array}{l}\text { Main } \\
\text { Menu }\end{array}$ & $\begin{array}{l}\text { Sesu } \\
\text { ai }\end{array}$ \\
\hline $\begin{array}{l}\text { Tomb } \\
\text { ol } \\
\text { Study }\end{array}$ & $\begin{array}{l}\text { on (release)\{ } \\
\text { stopAll } \\
\text { sounds(); } \\
\text { gotoAndPlay } \\
\text { ("materi"); } \\
\}\end{array}$ & $\begin{array}{l}\text { Menu } \\
\text { Study } \\
\text { stop(); } \\
\text { stopAllsounds( } \\
\text { ); } \\
\text { root.musik2.s } \\
\text { tart("0,9"); } \\
\text { root.musik2.s } \\
\text { etVolume(100) }\end{array}$ & \\
\\
\hline
\end{tabular}

\begin{tabular}{|c|c|c|c|}
\hline & $\begin{array}{l}\text { //on (release)\{ } \\
\text { gotoAndPlay } \\
\text { ("anggotaband } \\
\text { an"); } \\
\text { \} } \\
\text { //on (release)\{ } \\
\text { gotoAndPlay } \\
\text { ("benda"); } \\
\text { \} } \\
\text { //on (release)\{ } \\
\text { gotoAndPlay } \\
\text { ("binatang"); } \\
\text { \} } \\
\text { //on (release)\{ } \\
\text { gotoAndPlay } \\
\text { ("buah"); } \\
\text { \} } \\
\text { //on (release)\{ } \\
\text { gotoAndPlay } \\
\text { ("warna"); } \\
\text { \} }\end{array}$ & & \\
\hline $\begin{array}{l}\text { Tomb } \\
\text { ol } \\
\text { Exerci } \\
\text { se }\end{array}$ & $\begin{array}{l}\text { on (press) \{ } \\
\text { stopAllSounds( } \\
\text { ); } \\
\text { gotoAndStop(" } \\
\text { kuis"); } \\
\text { \} } \\
\text { //script } \\
\text { memasukan } \\
\text { nama } \\
\text { stop(); } \\
\text { nama_input="'" } \\
; \\
\text { //tombol star } \\
\text { on (release) \{ } \\
\text { dPlay(5); } \\
\text { \} } \\
\text { //Point Score } \\
\text { stop(); } \\
\text { point=score*10 } \\
; \\
\text { if (point >90) } \\
\text { gotoAndPlay(2 } \\
\text { 1); } \\
\text { nama=nama_i } \\
\text { nput; } \\
\text { nama_output= } \\
\text { nama; }\end{array}$ & $\begin{array}{l}\text { Exerc } \\
\text { ise }\end{array}$ & $\begin{array}{l}\text { Sesu } \\
\text { ai }\end{array}$ \\
\hline
\end{tabular}




\begin{tabular}{|l|l|l|l|}
\hline $\begin{array}{l}\text { Tomb } \\
\text { ol } \\
\text { Play } \\
\text { again } \\
\text { stopAllSounds( } \\
\text { ); } \\
\text { root.gotoAnd } \\
\text { Play(5); } \\
\}\end{array}$ & $\begin{array}{l}\text { Play } \\
\text { Again }\end{array}$ & $\begin{array}{l}\text { Sesu } \\
\text { ai }\end{array}$ \\
\hline $\begin{array}{l}\text { Tomb } \\
\text { ol } \\
\text { Back } \\
\text { To } \\
\text { Main } \\
\text { Menu }\end{array}$ & $\begin{array}{l}\text { on (release) }\{ \\
\text { gotoAndPlay(" } \\
\text { menu"); } \\
\}\end{array}$ & $\begin{array}{l}\text { Seles } \\
\text { ai }\end{array}$ & $\begin{array}{l}\text { Sesu } \\
\text { ai }\end{array}$ \\
\hline $\begin{array}{l}\text { Tomb } \\
\text { ol } \\
\text { Profile }\end{array}$ & $\begin{array}{l}\text { on (release) }\{ \\
\text { gotoAndPlay(" } \\
\text { menu"); }\end{array}$ & $\begin{array}{l}\text { Profil } \\
\text { e }\end{array}$ & $\begin{array}{l}\text { Sesu } \\
\text { ai }\end{array}$ \\
\hline $\begin{array}{l}\text { Tomb } \\
\text { ol } \\
\text { Home }\end{array}$ & $\begin{array}{l}\text { on (release) }\{ \\
\text { gotoAndPlay(" } \\
\text { menu"); } \\
\}\end{array}$ & $\begin{array}{l}\text { Kemb } \\
\text { ali }\end{array}$ & $\begin{array}{l}\text { Sesu } \\
\text { ai }\end{array}$ \\
\hline $\begin{array}{l}\text { Tomb } \\
\text { ol Exit }\end{array}$ & $\begin{array}{l}\text { on (release) }\{ \\
\text { fscom } \\
\text { mand } \\
\text { ("quit",true) } \\
\}\end{array}$ & Exit & $\begin{array}{l}\text { Sesu } \\
\text { ai }\end{array}$ \\
\hline
\end{tabular}

\section{SIMPULAN DAN SARAN}

Berdasarkan pemaparan di atas hasil penelitian dan pengembangan dapat di Tarik beberapa simpulan sebagai berikut : (1) Siswa siswi yang mencoba animasi edukasi Bahasa Inggris tingkat dasar rata rata memberikan respon yaitu $77 \%$. Pengembangan animasi ini pada mata pelajaran Bahasa Ingris untuk siswa tingkat dasar mampu memberikan kemudahan mengingat dan memahami kata kata dalam Bahasa Inngris bagi siswa tingkat dasar, ini di buktikan dengan hasil respon siswa yaitu $77 \%$ jika di Tarik kesimpulan termasuk dalam katagori baik.. (2) Pentingnya usaha kognitif dalam belajar harus diperhatikan. Agar dapat belajar secara efektif dengan animasi, murid harus memiliki cukup waktu dan sumberdaya mental untuk menerima dan mengkomprehensikan hubungan fungsional antar komponen komponen system. (3) Aplikasi ini merupakan media pembelajaran yang menarik bagi anakanak, sehingga mereka akan lebih bersemangat alam memahami materi pembelajaran Media pembelajaran ini mudah didapat

Dari hasil penelitian yang di peroleh maka : (1) Sebelum menerapkan suatu motode pembelajaran, sebaiknya diamati terlebih dahulu karakteristik siswa serta karakteristik materi yang akan diberikan perlakuan untuk mendapatkan hasil yang lebih baik Agar menarik minat anak, buatlah aplikasi seimajinatif mungkin. (2) Peneliti diharapkan mempersiapkan

penilaian siswa ketika proses permainan. (3) Hasil penelitian menunjukkan bahwa siswa yang belajar dengan animasi edukasi Bahasa Inggris tingkat dasar memperoleh hasil belajar yang lebih cepat mengingat Bahasa lgngris daripada siswa yang tidak menggunakan menggunakan animasi edukasi Bahasa Inggris tingkat dasar. Oleh karena itu, penulis menyarankan kepada para orang tua bahwa model pembelajaran dengan animasi lebih cepat di mengerti. Disarankan penelitian lain agar melaksanakan penelitian sejenis dengan pemilihan materi yang berbeda dan waktu yang lebih lama untuk mendapatkan hasil belajar siswa yang lebih rinci.

\section{DAFTAR RUJUKAN}

Andi. 2011. Kupas Tuntas Adobe FLASH Professional CS5. Yogyakarta : Andi.

Carvalho, L., Marroquim, R., \& Vital Brazil, E. (2017). DiLight: Digital light table Inbetweening for 2D animations using guidelines. Computers and Graphics (Pergamon), 65, 31-44. https://doi.org/10.1016/j.cag.2017.04. 001

García, R. R., Quirós, J. S., Santos, R. G., González, S. M., \& Fernanz, S. M. (2007). Interactive multimedia animation with Macromedia Flash in Descriptive Geometry teaching. Computers and Education, 49(3), 615-639.

https://doi.org/10.1016/j.compedu.200 5.11 .005

Gouaty, G., Fang, L., Michelucci, D., Daniel, M., Pernot, J. P., Raffin, R., ... Neveu, M. (2016). Variational 
geometric modeling with black box constraints and DAGs. CAD

Computer Aided Design, 75-76, 1-

12.

https://doi.org/10.1016/j.cad.2016.02.

002

Nadiyah, R. S., \& Faaizah, S. (2015). The

Development of Online Project Based

Collaborative Learning Using ADDIE

Model. Procedia - Social and

Behavioral Sciences, 195, 1803-

1812.

https://doi.org/10.1016/j.sbspro.2015.

06.392

Novitasari, D. R. (2010). Pembangunan

Media Pembelajaran Bahasa Inggris

Untuk Siswa Kelas 1 Pada Sekolah

Dasar Negeri 15 Sragen. Journal

Speed - Sentra Penelitian

Engineering Dan Edukasi-, 2(1), 21-

28. Retrieved from

http://www.ijns.org/journal/index.php/

speed/article/download/867/855

Widada,HR. 2010. Paling Dicari belajar

animasi 2D Dan 3D. Yogyakarta :

MediaKom 